\title{
Optimization Of Debtor Information Systems In Pressing Problem Financing In Some Syari'ah BPR In Aceh Province
}

\author{
Zulfan Yusuf ${ }^{1}$, Syamsul Rizal ${ }^{2}$ \\ ${ }^{1}$ Serambi Mekkah University, Banda Aceh, Indonesia \\ ${ }^{2}$ AKUBANK Nusantara, Aceh Timur, Indonesia \\ ${ }^{1}$ Zulfanyusuf01@gmail.com, ${ }^{2}$ syamsulrizal@akubanknusantara.ac.id
}

\begin{tabular}{l} 
Article Info \\
\hline Article history: \\
Received November 202020 \\
Revised December 282020 \\
Accepted January 22021 \\
\hline Keywords: $\quad$ Financing, \\
Bad Credit / Debtor, \\
Information Systems, Dank competitiveness \\
Bank
\end{tabular}

\begin{abstract}
Article 1 paragraph (1) of Law Number 10 the Year 1998 states that banking is a financial institution that collects funds from the public in the form of savings, time deposits, and demand deposits and which can be equated with them. Furthermore, it is channeled back to the public in the form of credit (financing in the Syari'ah Bank), with the aim of achieving people's welfare. Furthermore, based on Law Number. 21 of 2008 explains that a Syari'ah bank is a bank financial institution that runs its operations in a Shari'ah manner. One of the duties of banking institutions is to channel credit/financing to the public so that it can spur economic growth in the informal sector in the Region and National in the context of the Unitary State of the Republic of Indonesia. In the provision of credit/financing, it is not uncommon for fraudulent (internal) practices carried out by loan officers (AO / FO), finance staff, so that they can worsen Non-Performing Loans / Financing, which in turn can undermine the bank's own capital. The debtor information system is a strategic effort to minimize the occurrence of nonperforming loans so that the quality of financing can still be controlled at all times. The collectability of financing can also be used as a benchmark in increasing the competitiveness and selling value of a bank. The purpose of this study is to determine the extent to which banking institutions, in this case, the Islamic People's Financing Bank have implemented these provisions, what obstacles were found, and efforts to resolve them. This type of research is an Empirical Juridical, namely examining the Regulations governing Anti Money Laundering (APU) and the Prevention of Terrorism Funding (PPT) as well as Debtor Information within the scope of the financing process in several Sharia Rural Banks (BPRS) in Aceh Province. Based on research in eleven Sharia People's Financing Banks in Aceh Province, it is known that $68.3 \%$ have operational procedures (sop) on AML and CFT and run them well, while $31.7 \%$ have AML and CFT regulations, but have not implemented them optimally. . The reason why this provision has not been implemented optimally is that more intensive socialization is needed to related parties, including bank debtors, considering that debtors are prime customers in growing a bank.
\end{abstract}

Corresponding Author:

Zulfan Yusuf

Universitas Serambi Mekkah, Banda Aceh, Indonesia

Zulfanyusuf01@gmail.com

\section{INTRODUCTION}

A bank is a financial institution that plays an important role in advancing the economy of a country, in a narrower context it is a financial institution that collects public funds in the form of savings and deposits 
or something equivalent and distributes them back to the public in the form of credit for the welfare of the community[1]. The bank is a business that operates in the field of trust, which in this case acts as a financial intermediate medium between debtors and creditors [5]. Currently, the number of banking institutions has experienced very significant development, both in the capital city of the country, province, and even district/city whose distribution is considered to be increasing every year.

The number of Syari'ah banks in the last ten years is considered to have experienced very significant development, this is inseparable from the increasing public need for Islamic banking services; ah, apart from that the presence of Syari'ah banks along with other products and services owned by banks Shari'ah is not fully aimed at Ummad Islam alone, on the contrary, it can be used by all groups and beliefs of the community, meaning that anyone can become and simultaneously take advantage of various facilities at a Syari'ah bank.

The development of a Syari'ah bank must of course be supported by the availability of adequate Human Resources (SDI), both in terms of quality and quantity, so that the presence of skilled human resources can directly increase the competitiveness and selling power of Syari'ah banks, including therein. BPR Syari'ah in Indonesia, especially in Aceh Province.

Minimizing problematic financing is very much determined by the sharpness of the Financing Analyst Team, starting when determining the form of business to be financed and developed by the bank to the ability to determine the amount of ceiling that can be realized, in addition to the availability of a centralized Debtor Information System (SID) at Bank Indonesia, Jakarta. However, even though the provision of financing has implemented the prudent banking principles, there will still be problematic financing, even non-performing loans, these conditions can weaken the country's economic system and it is possible that the State will experience a structured negative growth. In a financial institution, service is very important and becomes the concern of all parties, both from service delivery and consumers [6].

From the results of previous research, it is known that not all Sharia Rural Banks (BPRS) in Aceh Province have implemented the AML and CFT regulations maximally, while the debtor information system, which is expected to be a shield in minimizing the occurrence of problematic financing, has not produced optimal results.

Based on the aforementioned problems, it motivates us to study and examine, as follows:

a. Has the Sharia Rural Bank in Aceh Province implemented the AML and CFT regulations

b. Are there any obstacles in carrying out these obligations

c. To what extent is the debtor's information considered effective in minimizing problematic financing, in particular the occurrence of white-collar crime at the Sharia People's Financing Bank in Aceh Province.

\section{RESEARCH METHOD}

Legal research is basically a scientific activity based on certain methods, systems, and thoughts, which aims to study one or several specific legal phenomena [2]. By analyzing it and then conducting an indepth examination of these legal factors to appear in the symptoms concerned. Therefore, the implementation of this research was carried out by first determining the research mechanism, as follows:

\subsection{Types and Research Approaches}

This type of research is an empirical Juridist, which means that this research seeks to study and examine the Anti Money Laundering (AML) and Terrorism Funding Prevention (PPT) regulations, as regulated in Law Number 8 of 2010, concerning Money Laundering and Identification. Debtors, as stipulated in the Financial Services Authority (OJK) regulations. Furthermore, to improve the quality of the research results, all the materials that have been collected will be identified and compiled systematically and conclusions are drawn in relation to the problem to be studied. In this study, the concept of normative law is used in the statutory system and positive law of Indonesia, thereby researched is positive law which is a doctrinal/normative law concept.

\subsection{Location and Population}

This research was conducted in Aceh Province, where there is a Sharia Rural Bank (BPRS), which runs the Anti-Money Laundering Program (APU) and the Prevention of Terrorism Funding (PPT), and Debtor Information as a shield to minimize the occurrence of problem financing. Meanwhile, the population is eleven Sharia People's Financing Banks scattered, starting in the cities of Banda Aceh, Aceh Besar, East Aceh, Lhokseumawe, Bireuen, Aceh Tengah, and Pidie. 


\subsection{Research Samples}

Considering that the number of Sharia People's Financing Banks (BPRS) in Aceh Province is only 11 units, the total is used as the sample and population of this study. The head office of the Sharia People Financing Bank is located as follows: a) Banda Aceh has 2 units (BPRS Hikmah Wakilah and Mustaqim); b) Aceh Besar has 1 unit (BPRS Baiturrahman); c) East Aceh, there are 2 units (BPRS Adeco and Serambi Mekkah); d) Lhokseumawe City has 1 unit (BPRS Rahmah Hijrah Agung); e) Bireuen Regency, there are 2 units (BPRS Kota Juang and Rahmania Dana Sejahtera); f) Aceh Tengah, there is 1 unit (BPRS Aceh Tengah); g) North Aceh has 1 unit (BPRS Aceh Utara); h) Pidie Regency has 1 unit (BPRS Tgk Chiek Dipanthe).

\subsection{Data source}

Sources of data were obtained through library research, namely by collecting data containing direct quotations. Summaries and ideas obtained from laws and regulations, books, magazines, journals, and prepositions of scientific works. Furthermore, the main research materials are:

a. The primary legal material is Law Number. 8 of 2010, concerning the Crime of Money Laundering, Law No. 10 of 1998, concerning Banking, Law No. 21 of 2007, concerning Islamic Banking and PBI No. 11/28 / PBI / 2009, dated 1 July 2009, concerning the Anti Money Laundering Program.

b. Secondary legal material, namely other reading material, as long as it provides an explanation of the primary material.

c. Tertiary legal materials, namely in the form of encyclopedias and legal dictionaries that provide explanations of legal terms used in banking crimes and money laundering.

\subsection{Data collection technique}

Data collection is obtained by conducting library research (library research), by studying documents, reference books, laws and regulations, articles, and scientific writings that are related to the problem under study. In addition, data can also be obtained from interviews with sources who are directly involved with the problems being studied, this is done to get a complete picture of the implementation of Bank Indonesia regulations and the Financial Services Authority (OJK) as Micro Prudential in supervising Banking Institutions in Indonesia.

\subsection{Data analysis}

After the library research data and field research data obtained from interviews are collected, it is then identified and analyzed based on similar data which are qualitative in nature and interpreted juridically, logically, and systematically, using inductive and deductive methods.

By using the inductive and deductive methods, results and benefits will be obtained from the implementation of the anti-money laundering program at the Sharia Rural Bank, as well as the sanctions imposed on Sharia Rural Banks that do not apply these provisions in their operations.

\section{RESULTS AND ANALYSIS}

\subsection{Understanding and the Legal Basis of Prudential Principles}

The principle of prudence (Prudent banking principle) is a principle or principle which states that in carrying out its functions and business activities, a bank is obliged to be prudent in protecting public funds entrusted to it.

In conducting its business, Indonesian banking is based on the principle of economic democracy using prudential principles [3]. Prudential principle or also known as Prudential banking is a very important principle in banking practice in Indonesia, so it must be applied and implemented in banking practice.

The term prudent is also known in the activities of bank supervision and inspection, both carried out by the Financial Services Authority (OJK) in the framework of fostering Banking Institutions which are carried out annually and carried out by the Board of Commissioners as an extension of the bank owner's hand.

The precautionary principle requires the bank to always be careful in managing the bank's business or in the sense that it must be consistent in implementing laws and regulations in the banking sector based on 
professionalism and good faith, literally prudential implies prudence and/or risk control through the application of laws and regulations. -the laws that apply consistently and continuously.

Despite Law No. 10 of 1998 does not clearly explain the definition of prudential principles, but the provisions regarding prudential banking are explicitly implied in the intended Law, among others:

a. The precautionary principle is also stated in Article 2 of Law no. 10 of 1998, concerning banking, that in conducting its business, Indonesian banking is based on economic democracy by using prudential principles.

b. The importance of applying prudential principles in every banking business activity is also mentioned in Article 29 paragraphs 2,3 and 4, namely;

1. Banks are required to maintain the soundness level of the bank in accordance with the provisions of capital adequacy, asset quality, management quality, liquidity, profitability, solvency, and other aspects related to bank business.

2. In disbursing financing and/or carrying out other business activities, banks are required to take methods that are not detrimental to the bank and the interests of customers who have entrusted their funds with the bank.

3. For the benefit of debtors, banks are required to provide information regarding the possibility of risk of loss related to debtor transactions conducted through banks.

c. The application of the prudential principles of Syari'ah banks is regulated in Article 35 paragraph 2, 3, 4 and paragraph 5 of Law no. 21 of 2008, concerning Syari'ah banks, among others, states, as follows:

1. Whereas Syari'ah commercial banks (BUS), Syari'ah business units (UUS) are required to submit financial reports to Bank Indonesia in the form of an annual balance sheet and profit and loss account and an explanation of which is prepared based on the generally accepted principles of Shari'ah accounting and periodic reports. others, in the time and form stipulated by Bank Indonesia regulations.

2. Whereas the annual balance sheet and profit/loss calculation must be audited first by a public accounting firm, then the balance sheet and profit/loss report must be announced to the public in a time and format determined by Bank Indonesia, however, there is an exception to the Syari'ah People's Financing Bank.

The exceptions referred to in point 2 above are specifically given to Syari'ah Commercial Banks (BUS), Syari'ah Business Units (UUS) and Syari'ah People's Financing Banks (BPRS).

\subsection{The Principle of Prudence}

The principle of prudence is a principle which states that in carrying out its functions and business activities, it is mandatory for banks to apply the prudential principle [1], this aims to protect public funds that are deposited and entrusted with better management of the bank. With the implementation of the precautionary principle, it is hoped that the level of public trust in Syari'ah banks, especially Syari'ah BPRs, will increase so that the selling price of banks will be higher and they are ready to compete with banking institutions in a competitive and professional manner.

Prudential principles are also applied in the process of analyzing prospective debtors and business sectors that will be financed and developed by the bank, with the aim of finding and identifying good, honest and responsible sectors and potential debtors.

Finding good, honest and responsible debtor candidates is not an easy job, but by using a number of criteria that are generally used by conventional banking institutions and other Shari'ah, at least the bank can detect dishonest people from the start and/or providing an early warning (Early Warning System) to the Management so that a fast and appropriate solution can be found in minimizing banking crimes. By optimizing the Decision Support System so that it can take into account all the criteria that support decision making to help, accelerate and simplify the process that is being implemented [7].

If the principles of consistent prudence are carried out by every bank actor, starting from the management level to the lowest level, then it is certain that there will be no fraud and other banking crimes at the bank, because these crimes occur in addition to opportunities and opportunities, but the need and demands of life It cannot be denied, even from several cases that have occurred recently in Banking 
Institutions, most of them are caused by changing behavior as a result of shifting the life pattern of the perpetrators themselves.

\subsection{Bank Health Standards (Prudential standard)}

The principle of prudence in its implementation refers to a stipulation or standard in order to keep the bank's business activities healthy and stable. Bank health signs or standard Prudential aim to enable banks to carry out their business activities safely and healthily.

The health standards in question are as follows:

\section{a. Financing Analysis.}

Banks are always required to conduct an initial assessment when prospective debtors apply for financing based on the $5 \mathrm{C}+1 \mathrm{C}$ and 7P. according to Vertical, et al. (2008), in the book Financial Management Theory, Concepts and Practical Guide Applications for Financial Institutions, Customers, Practitioners and Students, he explains about financing protection that the precautionary principle is the principle for protecting financing from various problems with potential candidates. Debtor, either through the identity of the prospective debtor and other supporting documents, namely:

\section{Character (character)}

Character is the nature and/or personality of a potential debtor that must be known by the bank, such as personal matters, habits, way of life and family background, so that from this knowledge it can be seen whether the potential debtor is honest and has characteristics. another positive. Thus at the time of the debtor getting financing facilities from the bank is able to carry out the mandate of the bank as well as possible.

2. Capacity (ability)

Capacity is the ability of prospective debtors to manage their business, which can be seen from their educational background, business experience, history in business so that it can be measured to what extent the prospective debtors are able to carry out their obligations to the bank.

3. Capital (capital)

The condition of the assets owned by the prospective debtor which can be seen from the Financial Statements and Profit/Loss presented to the bank will be used as the basis for the bank's consideration in realizing and determining the amount of the financing limit given to the prospective debtor.

4. Collateral (collateral)

Collateral is collateral and/or bought owned by prospective debtors, the collateral can be in the form of movable and immovable objects. The collateral value to be placed in the bank should be greater than the financing facility received by the prospective debtor so that when the prospective debtor is unable to carry out its obligations to the bank, the bank can easily sell the guarantee to a third party. Therefore, the bank before disbursing financing to the prospective debtor is obliged to carefully examine the validity of the guarantee, so that no claims are made by third parties against the collateral placed in the bank.

\section{Condition of Economic (economic conditions)}

The financing provided must always consider economic conditions and Government policies in the economic sector so that it is hoped that there will be wide opportunities in the marketing of products produced by prospective debtors, as well as of course it will make it easier for banks to control the prospective debtor's own business.

Furthermore, in analyzing potential debtors, it is also strengthened by the $7 \mathrm{P}$ analysis method, as follows:

\section{Personality (personality)}

Banks are expected to be able to assess the personality of the prospective debtor, such as their behavior and their relationship to their past. Does the prospective debtor get angry quickly and/or like to say dirty words and so on.

2. Party (group)

As far as possible, the bank tries to classify prospective debtors who are financed based on the amount of capital they have, the level of loyalty in carrying out their obligations to the bank and the sine of belonging, or the extent to which the prospective debtors are concerned about the bank. This is done to make it easier for the bank itself to control and manage the level of risk in providing financing.

3. Purpose (purpose)

Since the beginning, the bank has confirmed the purpose of the prospective debtor to take out the financing facility, whether for consumption, working capital and/or other investments. This 
condition will make it easier for the bank itself to foster and anticipate the failure of the prospective debtor's business when faced with unexpected conditions that may occur at any time.

4. Prospect (prospect)

Banks are expected to be able to read the opportunities and levels of market saturation when prospective debtors apply for certain financing facilities to be financed by the bank so that the bank can predict from the beginning the selling value of a product that will be produced by the prospective debtor, thus the bank has indirectly minimized the failure rate. the debtor's own business.

5. Payment (source of payment)

Since conducting a financing analysis of potential debtors, as far as possible, the bank will explore whether the prospective debtor has other businesses besides managing the business that will be financed and developed by the bank, this is intended to secure when the prospective debtor is less successful in managing the business financed by bank. The more sources of payment the prospective debtor has, the better.

6. Profitability (ability to pay profit)

As far as possible, the bank studies and analyzes the extent to which potential debtors are able to generate profits from the business they manage, of course, the bank periodically checks on the spot to see directly the prospective debtors in running their business, because it is not impossible that waste and inefficiency in managing the business, such as giving bonuses and/or discounts to third parties without taking into account the profit side of the products sold and so on.

7. Protection (protection)

As far as possible, the bank must protect against the financing provided to prospective debtors, this protection can be in the form of a financing guarantee (bought), a person guarantee (bought touch) and/or a guarantee from an insurance company. This means that when the debtor fails to manage his business the bank is not too difficult to settle the debtor's obligations, because there are still other parties who are willing to accept the transfer of risk and/or can ask for risk reimbursement from other third parties.

b. Maximum Limit of Financing (BMPD)

The stipulation of the Legal Lending Limit (BMPD) by the Financial Services Authority (OJK) for each Banking Institution aims to make banks spread risk and equalize the use of their own financing, this is in line with the objective of establishing a Banking Institution as stipulated in Law No. 10 of 1998, concerning banking.

On the other hand, with this provision, banks must also reduce the level of financing risk as much as possible, of course by increasing the number of debtors and not concentrating only on a few core debtors, who receive large amounts of financing facilities, because their failure to manage their business has a direct negative impact. against the bank, which will worsen the quality of the productive assets (KAP) of the bank itself. However, if the risk is more widespread, then the failure of one debtor can be backed up by another debtor so that the bank is unlikely to experience systemic losses.

c. Bank Capital Adequacy Ratio (KPMM)

Based on the provisions of the Financial Services Authority (OJK), every banking institution is required to maintain a minimum CAR of $12 \%$, measured from the availability of bank core capital, and will subsequently undergo changes in accordance with the management of the bank's productive assets, as is the case with BPR Syari'ah, which is always required to maintain the ratio. capital of the amount mentioned above. Thus BPR Syari'ah can operate properly and smoothly.

d. Earning Asset Quality (KAP)

In line with the provisions of Bank Indonesia No. 7/2 / PBI / 2005, regarding Earning Asset Quality Assessment for Commercial Banks, explains that earning assets are the provision of bank funds to obtain profits, both in the form of financing, securities, interbank fund placements, acceptance receivables, claims on securities purchased by a reverse repurchase agreement and so on which can be equated with it. In the context of implementing prudential principles, Management is obliged to assess, monitor, and take the necessary steps so that the quality of the bank's earning assets remains sound and safe.

\subsection{Implementation of Prudential Principles at BPR Syari'ah Aceh}

As an implementation of the Government Policy in the October 1988 Package some time ago the Aceh Government, led by Prof. DR. Ibrahim Hasan, MBA at that time served as Governor of Aceh initiated 
the establishment of several BPR Syari'ah in Aceh Province and Alhamdulillah around 1993 - 1995 there were 3 (three) Syari'ah BPRs, including BPR Syari'ah Baiturrahman, BPR Syari'ah Hikmah Wakilah, and BPR Syari'ah Hareukat, all of which initially operated in Aceh Besar, are expected to have the presence of BPR Syari'ah to spur the growth and development of the same economic institutions throughout Aceh Province so that they can access capital needs for the people of Aceh through improving the informal and industrial sectors. households scattered in the interior of Aceh.

Alhamdulillah, in a period of approximately 25 years, the number of BPR Syari'ah in Aceh Province increased by 9 (nine) more units, so that all of them became 12 (twelve) units, which are spread across the eastern part of Aceh, namely Pidie District, East Aceh, Central Aceh, Lhokseumawe, and Bireuen. It is hoped that in the next 10 years there will be several more Syari'ah BPRs in the western and southern parts of Aceh Province so that the existence of these micro banking institutions can strengthen the economic fundamentals of the Acehnese people equally.

The development of third party funds for the Aceh Sharia Islamic People Financing Bank in the last 3 (three) years amounting to Rp. 373 billion, while the financing disbursed was Rp. 287 billion. Furthermore, the total assets amounted to Rp. 550 billion, with the amount of Non-Performing Financing (NPF) of 3.7\%. This means that BPR Syari'ah in Aceh Province has carried out its duties and functions properly as mandated by Law no. 21 of 2008, concerning the Syari'ah Bank.

With regard to the management of financing risk based on the results of our monitoring at the Aceh Sharia Rural Bank shows excellent results, meaning that the management monitors and controls the collectability of financing at all times below the number 5 in accordance with the provisions set by the Financial Services Authority (OJK),

There are several factors that determine the Non-Performing Financing (NPF) of BPR Syari'ah Aceh to be below 5\%, as follows:

\section{a. Keeping Integrity High}

To achieve Good Corporate Governance (GCG) in Banking Institutions, especially BPR Syari'ah Aceh, Management always upholds and is committed to implementing high integrity, not confusing halal with non-halal, this must be able to be applied in day-to-day bank management. , including in determining attitudes and taking important decisions in providing financing to debtors and resolving financing that is already problematic, thus the level of public trust is getting higher and can be maintained properly, which in turn the selling price of the bank remains high and able to compete with banking institutions others in a healthy and competitive manner.

b. Increase Competence From Time To Time

In dealing with competitors, BPR Syari'ah Aceh always provides the best service to the community, in addition to continuing to diversify bank products, both in the form of modification and verification in accordance with the demands and needs of the community.

Furthermore, based on the research we conducted at BPR Syari'ah Aceh, it illustrates that the Management annually organizes training and/or training given to Human Resources (SDI) in accordance with their respective fields of duty, of course in collaboration with independent training institutions that have national level qualifications. Apart from being routinely organized by the Aceh Province Financial Services Authority (OJK) and the center in Jakarta in collaboration with the Association of BPRs throughout Indonesia, the branch of Aceh Province.

c. Debtor Information System as Debitor Early Warning System

The debtor information system is a method or action to determine the current condition of a person and/or legal entity that has integrated financial access with one and/or several banks in Indonesia. Bank Indonesia is the sole authority in assessing whether a person is good or not in accessing banking institutions in Indonesia.

As a micro bank, the Sharia Rural Bank (BPRS) in Aceh Province has utilized the function of the debtor information system as an early warning system in determining the feasibility of the prospective debtor to be financed, so that the bank is not trapped by the real condition of the prospective debtor, thus the bank can periodically maintain and managing the level of financing risk. Furthermore, in implementing the implementation of the Anti Money Laundering Law (APU) and the Prevention of Terrorism Funding (PPT) based on our research in eleven Sharia People's Financing Banks, $68.3 \%$ already have AML and CFT provisions and run them optimally, meanwhile $31.7 \%$ have not implemented the AML and CFT provisions optimally.

\section{CONCLUSION}

Based on the description and explanation as mentioned above, it can be concluded, as follows: 
a. The principle of prudence is a principle which states that in running a bank business it is obligatory to be prudent and full of calculations so that the level of public trust can be maintained and increased from time to time.

b. The precautionary principle is the main foundation in achieving good corporate governance as regulated in Law no. 40 of 2007, regarding Limited Liability Companies.

c. The application of prudential principles and the debtor information system in bank management is an indicator in maintaining the quality of financing, in addition to minimizing the occurrence of problematic financing and other banking crimes.

d. The implementation of prudential principles in bank management can prevent fraud and other banking crimes so that selling prices and bank competitiveness can be continuously improved

e. Based on Law No. 8 of 2010 and Bank Indonesia Regulation (PBI) no. 11/28 / PBI / 2010, dated 1 July 2010, the Anti Money Laundering Program (APU) and the Prevention of Terrorism Funding (PPT) are provisions that must be owned and carried out by every Banking Institution, in this case, Sharia Rural Banks in Indonesia, especially in Aceh Province.

f. Based on the results of research on 11 Islamic People's Financing Banks in Aceh Province, 7 units or 68.3\% had Anti Money Laundering (APU) and Terrorism Funding Prevention (PPT) programs and implemented them properly and maximally, while 4 units or $31.7 \%$ have not implemented these provisions optimally.

g. The provision has not been implemented due to the need for further outreach to staff in charge of this field and also the need to involve the public as bank customers themselves, both already bank customers and prospective customers who will use the bank as a medium for investment.

h. With regard to the application of legal sanctions against Islamic People's Financing Banks that have not implemented the AML and CFT provisions for the initial stage, the Financial Services Authority (OJK) has only given a written warning, but starting from the beginning of 2021 there will be tougher sanctions and can even reduce the level of health. bank within a certain time.

\section{REFERENCES}

[1] Munir Fuady, Hukum Perbankan Modern, Edisi ketiga, PT. Citra Aditya Bakti, Bandung, 2015

[2] Soerjono Soekanto, Penelitian Ilmu Hukum, Universitas Indonesia, Jakarta. 1988

[3] Undang-Undang Republik Indonesia Nomor 10 Tahun 1998, tentang Perubahan Atas Undang Undang Nomor 7 Tahun 1992 tentang Perbankan, Lembaran Negara Tahun 1998, Nomor. 182

[4] Undang-Undang Republik Indonesia Nomor 21 Tahun 2008, tentang Bank Syari'ah, Lembaran Negara Tahun 2008, Nomor. 784

[5] Santoso, Rudi (2013). Kelembagaan Perbankan. Gramedia.Jakarta

[6] Rizal, S., \& Munawir, M. (2017). Pengaruh Kepuasan Nasabah Terhadap Menggunakan Mobile Banking (M-Banking) Pada Bank BCA Cabang Banda Aceh. Jurnal EMT KITA, 1(2), 68-78.

[7] Munawir, M., \& Ardiansyah, A. (2017). Decision Support System Pemilihan Karyawan Berprestasi Dengan Pendekatan Analisa Gap Profile matching Di Kantor Perwakilan Bank Indonesia Provinsi Aceh. Jurnal JTIK (Jurnal Teknologi Informasi dan Komunikasi), 1(1), 7-14. 